\title{
Supported Zinc Oxide Photocatalyst for Decolorization and Mineralization of Orange G Dye Wastewater under UV365 Irradiation
}

\author{
Ming-Chin Chang, Hung-Yee Shu, Tien-Hsin Tseng, and Hsin-Wen Hsu \\ Institute of Environmental Engineering, Hungkuang University, No. 34 Chung-Chie Road, Shalu, Taichung 433, Taiwan \\ Correspondence should be addressed to Hung-Yee Shu; hyshu@sunrise.hk.edu.tw
}

Received 18 August 2013; Revised 24 September 2013; Accepted 25 September 2013

Academic Editor: Jiaguo Yu

Copyright (c) 2013 Ming-Chin Chang et al. This is an open access article distributed under the Creative Commons Attribution License, which permits unrestricted use, distribution, and reproduction in any medium, provided the original work is properly cited.

\begin{abstract}
To solve the environmental challenge of textile wastewater, a UV/ZnO photocatalytic system was proposed. The objective of this study was to prepare a photocatalytic system by utilizing both cold cathode fluorescent light (CCFL) UV irradiation and steel mesh supported $\mathrm{ZnO}$ nanoparticles in a closed reactor for the degradation of azo dye C.I. Orange G (OG). Various operating parameters such as reaction time, preparation temperature, mixing speed, $\mathrm{ZnO}$ dosage, $\mathrm{UV}$ intensity, $\mathrm{pH}$, initial dye concentration, and service duration were studied. Results presented efficient color and total organic carbon (TOC) removal of the OG azo dye by the designed photocatalytic system. The optimal $\mathrm{ZnO}$ dosage for color removal was $60 \mathrm{~g} \mathrm{~m}^{-2}$. An alkaline $\mathrm{pH}$ of 11.0 was sufficient for photocatalytic decolorization and mineralization. The rate of color removal decreased with the increase in the initial dye concentration. However, the rate of color removal increased with the increase in the UV intensity. The steel mesh supported $\mathrm{ZnO}$ can be used repeatedly over 10 times without losing the color removal efficiency for 120 min reaction time. Results of Fourier transform infrared (FTIR) and ion chromatography (IC) indicated the breakage of $\mathrm{N}=\mathrm{N}$ bonds and formation of sulfate, nitrate, and nitrite as the major and minor products. The observation indicated degradation of dye molecules.
\end{abstract}

\section{Introduction}

In the last few decades, the textile industry is one of the most important industries, which make contribution toward Taiwan's economic development. Wastewater effluents from textile and dye manufacturing industries receive much attention from public and governmental enforcements, because this type of wastewater can hardly meet the national discharge standards. In Taiwan, the national effluent standard (NES) has enforced the criteria of textile dyeing industries that chemical oxygen demand (COD) meets $<100$ to $160 \mathrm{mg} / \mathrm{L}$ and American Dye Manufacturers Institute (ADMI) color index meets $<550$ unit by the year 2003. On the other hand, most dyestuffs from the effluent of textile dyeing and finishing industry are complicated organic compounds with high color intensity, are recalcitrant to conventional biological wastewater treatment, and cause major environmental concerns [1-4]. To resolve the wastewater treatment problem, textile industrial treatment plants usually employ chemical coagulation integrated with activated sludge process. Unfortunately, these traditional treatment processes cannot meet the increasingly stringent criteria of color in dye wastewater treatment in Taiwan [5]. Under this situation, textile dyeing industries should pursue a more efficient technique to be the pretreatment or polishing processes to decolorize the highly colored wastewater. In this category of wastewater, azo dyes with nitrogen double bond $(-\mathrm{N}=\mathrm{N}-)$ are the largest class of commercial dyestuffs used in the textile industries. Thus, many studies focused on decolorizing azo dye compounds by various techniques [6-8].

Advanced oxidation processes (AOPs), such as ozonation, $\mathrm{UV} / \mathrm{H}_{2} \mathrm{O}_{2}, \mathrm{UV} / \mathrm{O}_{3}, \mathrm{Fe}^{2+} / \mathrm{H}_{2} \mathrm{O}_{2}$, and $\mathrm{UV} / \mathrm{O}_{3} / \mathrm{H}_{2} \mathrm{O}_{2}$, are widely used to decompose organic products in industrial wastewater and groundwater. The extensive literatures of these technologies have been reviewed by Venkatadri and Peters [9]. These processes have the potential ability to mineralize most of the organic contaminants into carbon dioxide and water. There were reports of successful color removal with final 
mineralization from azo dye wastewater using advanced oxidation processes (AOPs) such as $\mathrm{UV} / \mathrm{H}_{2} \mathrm{O}_{2}[10-12], \mathrm{UV} / \mathrm{O}_{3}$ $[13,14]$, or the Fenton reaction $[15,16]$. Additionally, it has been reported that photocatalytic processes such as $\mathrm{UV} / \mathrm{ZnO}$ system can also be effective in treating dye wastewaters [1719]. The preparation of $\mathrm{ZnO}$ catalyst can be demonstrated by hydrothermal synthesis [20] and the doping of carbon on $\mathrm{ZnO}$ can improve its visible light application [21]. Much research focused on slurry type reactor. However, the limitation on the need of further separation of $\mathrm{ZnO}$ particles made the process more complicate and expensive. Therefore, fixing the $\mathrm{ZnO}$ particles onto supported materials such as glass plate, silica plate can avoid the particle separation step and can enable the easy operation of heterogeneous $\mathrm{ZnO}$ photocatalysis [22-24]. The aim of this work was to study the degradation of azo dye C.I. Orange G (OG) using a batch photocatalytic reactor in which the photocatalytic $\mathrm{ZnO}$ particles were supported on steel mesh and six cold cathode fluorescent lamps (CCFL) were used (wavelength of $365 \mathrm{~nm}$ ) to provide UV irradiation. Operating parameters such as preparation temperature, mixing speed, $\mathrm{ZnO}$ dosage, UV intensity, $\mathrm{pH}$, initial dye concentration, and reaction time that may affect the degree of the dye degradation were studied. Changes in color intensity, total organic carbon (TOC), $\mathrm{pH}$, oxidation reduction potential (ORP) were monitored in addition to the analysis of reaction products by Fourier transform infrared (FTIR) and ion chromatography (IC).

\section{Materials and Methods}

2.1. Materials and Apparatus. A mono-azo dye, C.I. Orange G (OG), was selected as target compound for this photocatalytic decolorization study. OG $\left(\mathrm{C}_{16} \mathrm{H}_{10} \mathrm{~N}_{2} \mathrm{Na}_{2} \mathrm{O}_{7} \mathrm{~S}_{2}, 60 \%\right.$ purity) with a characteristic wavelength $\left(\lambda_{\max }\right)$ of $479 \mathrm{~nm}$ and a molecular weight of $452.38 \mathrm{~g} \mathrm{~mole}^{-1}$ was purchased from Sigma-Aldrich, Inc. and used as received without further purification. The chemical structure of OG can be obtained from our previous study [25]. The commercial available nanosized zinc oxide $(\mathrm{ZnO})$, with a specific surface area of $25.68 \mathrm{~m}^{2} \mathrm{~g}^{-1}$ from Aldrich, was used as the photocatalyst. The steel mesh (mesh size no.140, $0.106 \mathrm{~mm}$ ) was purchased from a local hardware store and trimmed into pieces with a gross area of $252 \mathrm{~cm}^{2}(36 \times 7 \mathrm{~cm})$. A dip coating technique was used to prepare $\mathrm{ZnO}$-coated steel meshes. The trimmed steel mesh was washed, dried, and weighted first, then dipped into a designed concentration of $\mathrm{ZnO}$ mixed liquid for 30 minutes, and then dried in a $105^{\circ} \mathrm{C}$ oven for 30 minutes. The coating process was repeated three times. After all, the $\mathrm{ZnO}$ coated steel mesh was weighted to measure the amount of $\mathrm{ZnO}$ on steel mesh. The detailed preparation procedure was reported in our previous work with the replacement of $\mathrm{TiO}_{2}$ with $\mathrm{ZnO}$ nanoparticles [25]. Table 1 shows the steel mesh with specific surface. $\mathrm{ZnO}$ concentration of $8-67 \mathrm{~g} \mathrm{~m}^{-2}$ can be obtained by dip coating $0.20-1.67 \mathrm{~g}$ of $\mathrm{ZnO}$ nanoparticles on the given steel mesh with gross area of $252 \mathrm{~cm}^{2}$. Based on images obtained with the field emission scanning electron microscope (FESEM), model JEOL 6330CF, the bare steel
TABLE 1: The $\mathrm{ZnO}$-coated weight on the steel meshes.

\begin{tabular}{lccc}
\hline $\begin{array}{l}\mathrm{ZnO} \\
\text { weight }(\mathrm{g}) \\
\left(W_{1}\right)\end{array}$ & $\begin{array}{c}\text { ZnO solution } \\
\text { concentration } \\
\left(\mathrm{g} \mathrm{L}^{-1}\right) \\
\left(W_{1} / V\right)\end{array}$ & $\begin{array}{c}\text { ZnO weight on } \\
\text { the coated steel } \\
\text { meshes }(\mathrm{g}) \\
\left(W_{2}\right)\end{array}$ & $\begin{array}{c}\mathrm{ZnO} \text { weight } \\
\text { per unit area } \\
\left(\mathrm{g} \mathrm{m}^{-2}\right) \\
\left(W_{2} / A\right)\end{array}$ \\
\hline 15 & 30 & 0.20 & 8 \\
25 & 50 & 0.37 & 15 \\
37.5 & 75 & 0.75 & 30 \\
50 & 100 & 1.51 & 60 \\
62.5 & 125 & 1.67 & 67 \\
\hline
\end{tabular}

$V$ : the $\mathrm{ZnO}$ solution of $500 \mathrm{~mL}, A$ : the steel net area of $252 \mathrm{~cm}^{2}$.

mesh showed smooth surface with no particles attached as shown in Figures 1(a) and 1(b). As for $\mathrm{ZnO}$-coated steel mesh, it is seen that $\mathrm{ZnO}$ particles were uniformly coated on the steel mesh surface and the particles were of cylindrical shape as shown in Figures 1(c) and 1(d). The crystallinity of $\mathrm{ZnO}$ particles was provided by Aldrich as wurtzite structure. The photocatalytic reactor setup was also presented in our previous work [25]. The reactor was a $36 \mathrm{~cm}(L) \times 7 \mathrm{~cm}(W) \times$ $7.8 \mathrm{~cm}(H)$ black acrylics container fixed on a horizontal shaker with $75 \mathrm{rpm}$ mixing speed. At the upper cover of the reactor, six cold cathode fluorescent lamps (CCFL), each of which has a diameter of $0.25 \mathrm{~cm}$, length of $30 \mathrm{~cm}$, light intensity of $4 \mathrm{~W}$, and irradiation wavelength of $365 \mathrm{~nm}$, were equipped which yielded a total light energy of $2.1 \mathrm{~mW} \mathrm{~cm}^{-2}$ measured at the surface of the solution. In each experimental run, $200 \mathrm{~mL}$ dye solution was introduced to the photocatalytic reactor. At the bottom of the reactor, there was $\mathrm{ZnO}$ coated steel mesh with total gross surface area $252 \mathrm{~cm}^{2}$ placed.

2.2. Experimental Procedure and Analysis. OG azo dye solution at various concentrations was prepared with deionized water. The experimental variables studied included reaction time, preparation temperature, mixing speed, $\mathrm{ZnO}$ dosage, $\mathrm{UV}$ intensity, $\mathrm{pH}$, initial dye concentration, and application duration of $\mathrm{ZnO}$. At a predetermined reaction time, an aliquot of the solution was withdrawn and analyzed for residual dye concentration, TOC, and color.

Dye concentration was determined by measuring the absorbance at a wavelength of $479 \mathrm{~nm}$ using Hitachi U-2000 spectrophotometer. Color intensity was determined based on the American Dye Manufacturers Institute (ADMI) standard color measurement by applying the Adams-Nickerson color difference formula following method $2120 \mathrm{E}$ of the standard methods. The $\mathrm{pH}$ and redox potential (ORP) were monitored by a Eutech PH5500 dual channel pH/ion meter with specific probes. TOC was obtained with a total organic carbon analyzer from O.I. Analytical Aurora, model 1030. Besides, the degradation products were identified using Perkin Elmer FTIR spectrophotometer model, Spectrum One. Ions such as sulfate, nitrate, and nitrite were identified with ion chromatography (IC), Dionex ICS-1000. 


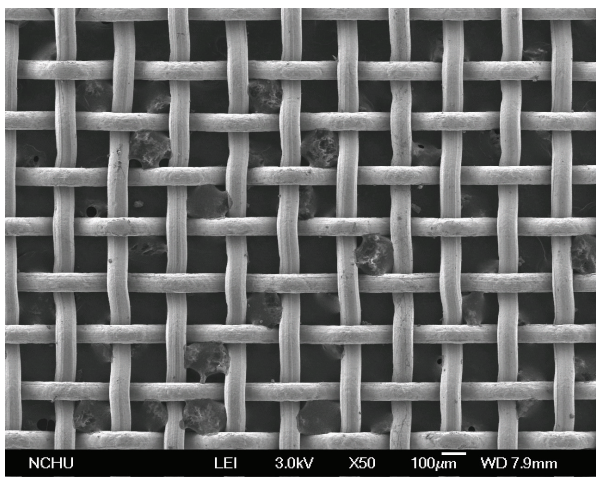

(a)

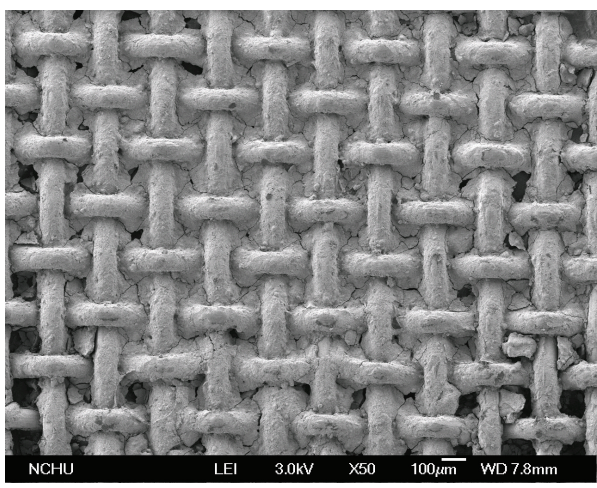

(c)

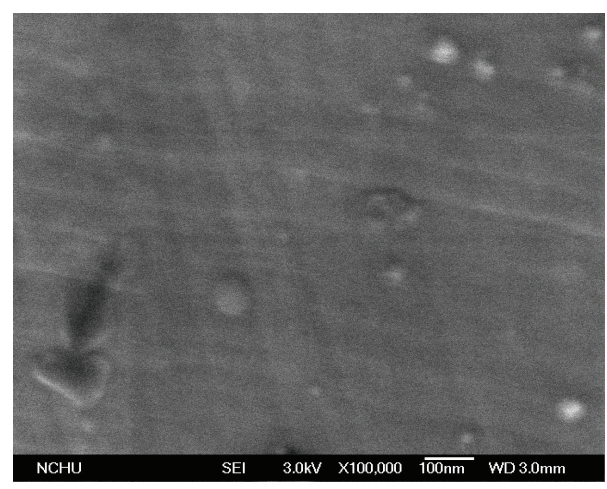

(b)

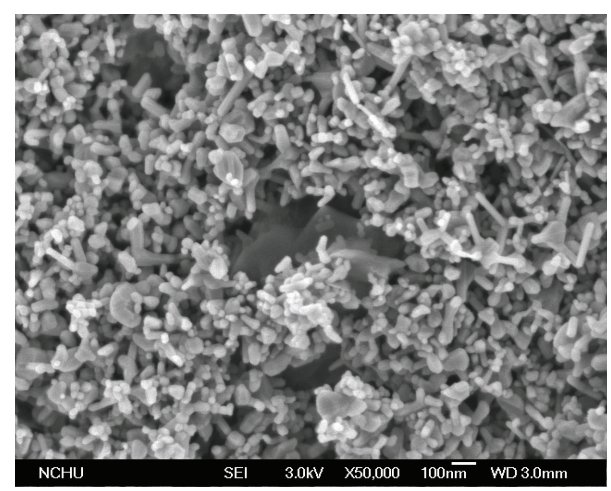

(d)

FIgURE 1: The morphology of $\mathrm{ZnO}$ powder coated on steel mesh at $150^{\circ} \mathrm{C}$ was identified by a JEOL 6330CF field emission scanning electron microscope (FESEM). (a) Bare steel mesh, 50 times enlargement. (b) Bare steel mesh, 100,000 times enlargement. (c) ZnO-coated steel mesh, 50 times enlargement. (d) $\mathrm{ZnO}$-coated steel mesh, 50,000 times enlargement.

\section{Results and Discussion}

3.1. Synergic Effect of Combining CCFL UV 365 Irradiation and $\mathrm{ZnO}$ Catalyst. The color removal was first compared for various systems, that is, $\mathrm{UV} / \mathrm{ZnO}, \mathrm{UV}$ alone, and $\mathrm{ZnO}$ alone, at the initial $\mathrm{OG}$ concentration of $50 \mathrm{mg} \mathrm{L}^{-1}, \mathrm{ZnO}$ dosage of $60 \mathrm{~g} \mathrm{~m}^{-2}$, and 6 CCFL lamps with total light intensity of $24 \mathrm{~W}$ and at wavelength of $365 \mathrm{~nm}$ in $120 \mathrm{~min}$ of reaction in the closed reactor. Figure 2(a) shows results of color removal by various systems. Results indicated that the system of UV alone and $\mathrm{ZnO}$ alone could not remove color at any significant level. The UV/ZnO system removed color effectively with $100 \%$ removal, in $120 \mathrm{~min}$. It was also observed that the $\mathrm{pH}$ remained relatively constant from 5.5 to 5.0 with time. This was expected as $\mathrm{ZnO}$ is a known photocatalyst that, upon radiation with light whose wavelength is shorter than that of its bandgap, can generate electron-hole pair and hydroxyl radicals, strong oxidation agents that can oxidize a wide group of organic compounds nonspecifically. Figure 2(b) shows the UV spectra of OG at different reaction time periods. There were three major absorption peaks for $\mathrm{OG}$ dye, that is, 248, 330, and $479 \mathrm{~nm}$. During the photocatalytic reaction, all three major absorption peaks were diminished. For example, at the wavelengths of 479, 330, and $248 \mathrm{~nm}$, the original absorbance was $1.8514,1.1891$, and 2.4417 , respectively. After 120 min of reaction, the absorbance of 479,330 , and
$248 \mathrm{~nm}$ changed to 0,0 , and 0.0145 , respectively. The figure illustrates the total removal of color by UV/ZnO system.

3.2. Effect of Preparation Temperature and Mixing Speed. The effect of steel mesh supported $\mathrm{ZnO}$ preparation temperature on color removal was studied at the initial OG concentration of $50 \mathrm{mg} \mathrm{L}^{-1}, \mathrm{ZnO}$ load dosage of $60 \mathrm{~g} \mathrm{~m}^{-2}$, and $6 \mathrm{CCFL}$ lamps in $120 \mathrm{~min}$ in the closed reactor. Figure 3(a) shows insignificant color removal differences in the range of 100$300^{\circ} \mathrm{C}$. It was noted that $\mathrm{pH}$ remained unchanged at around 5 to 6 . The reaction kinetics of $\mathrm{UV} / \mathrm{ZnO}$ photocatalytic system was suggested to follow the Langmuir-Hinshelwood (L-H) reaction kinetics. And, in most of the designed reaction conditions, the L-H kinetic model of the UV/ZnO system can be further simplified into pseudo-first-order reaction kinetics. Therefore, the color removal of this study was treated using pseudo-first-order reaction as follows:

$$
C_{\text {dye }}=C_{\text {dye }, 0} \times e^{-k t},
$$

where $k$ denotes the pseudo-first-order reaction rate constant $\left(\mathrm{min}^{-1}\right), t$ is the reaction time $(\mathrm{min}), C_{\text {dye }, 0}$ designates the initial concentration $\left(\mathrm{mg} \mathrm{L}^{-1}\right)$ of $\mathrm{OG}$, and $C_{\text {dye, } t}$ is the concentration $\left(\mathrm{mg} \mathrm{L}^{-1}\right)$ of $\mathrm{OG}$ at time $t$. The curve fitting of experimental results by (1) was shown in the figures as solid lines to demonstrate the consistence of kinetic model and 


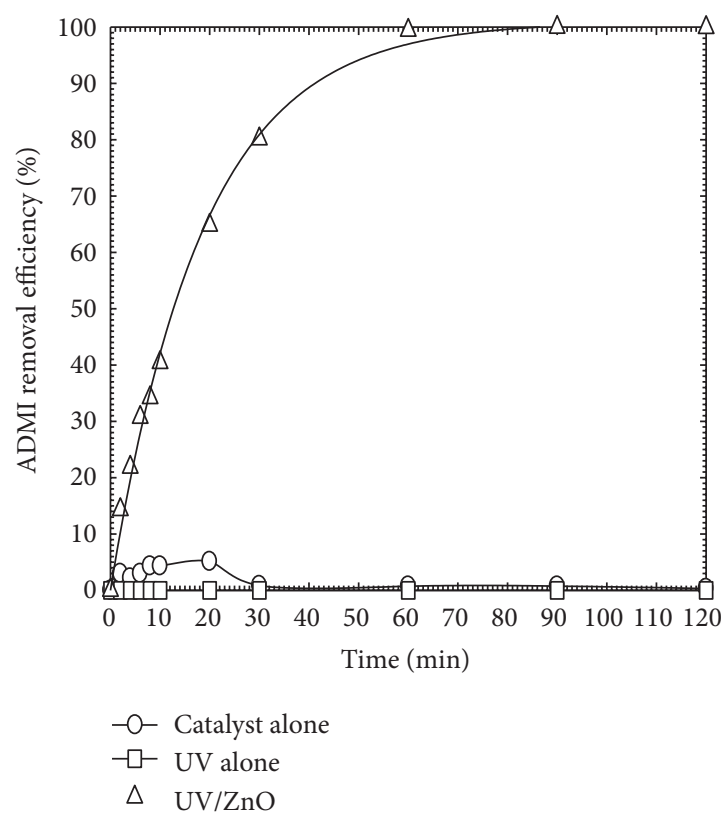

(a)

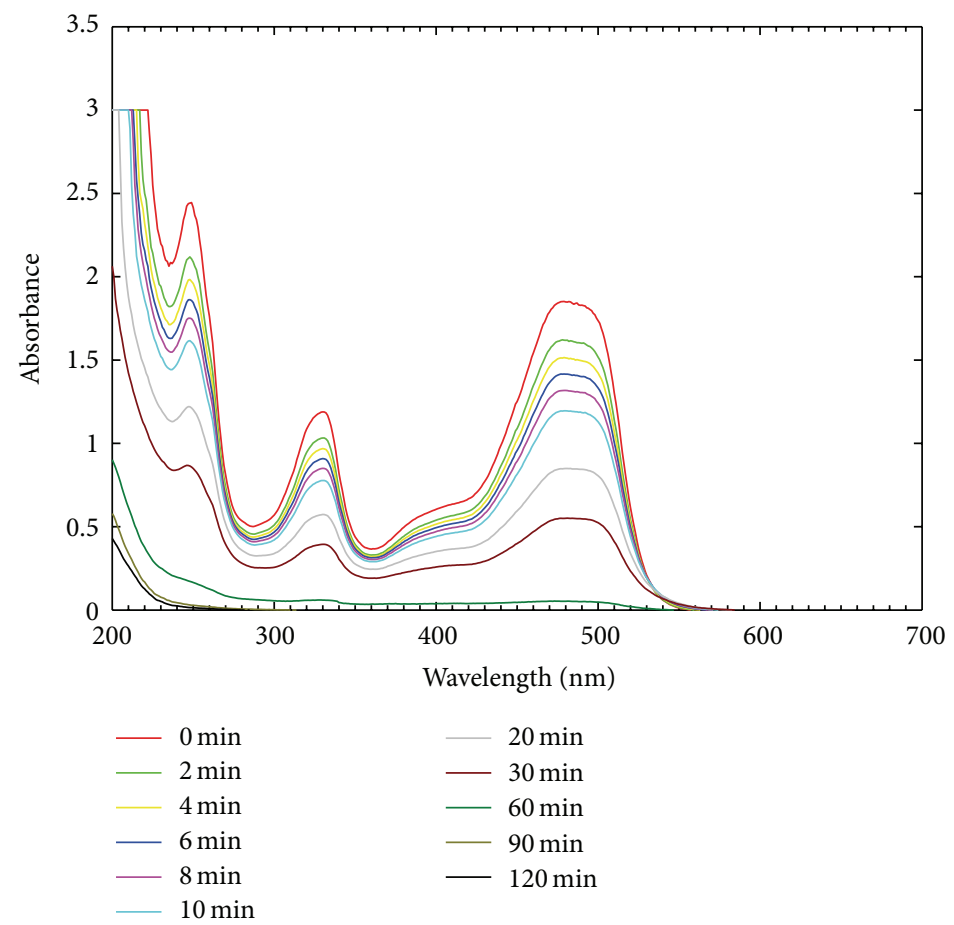

(b)

FIGURE 2: (a) Synergic effect of UV and $\mathrm{ZnO}$ on UV/ZnO photocatalytic system. (b) UV spectra of OG under UV/ZnO decolorization. The conditions were initial dye concentration of $50 \mathrm{mg} \mathrm{L}^{-1}, \mathrm{ZnO}$ loading of $60 \mathrm{~g} \mathrm{~m}^{-2}$, light intensity of $2.1 \mathrm{~mW} \mathrm{~cm}^{-2}$, and reaction time during $120 \mathrm{~min}$.

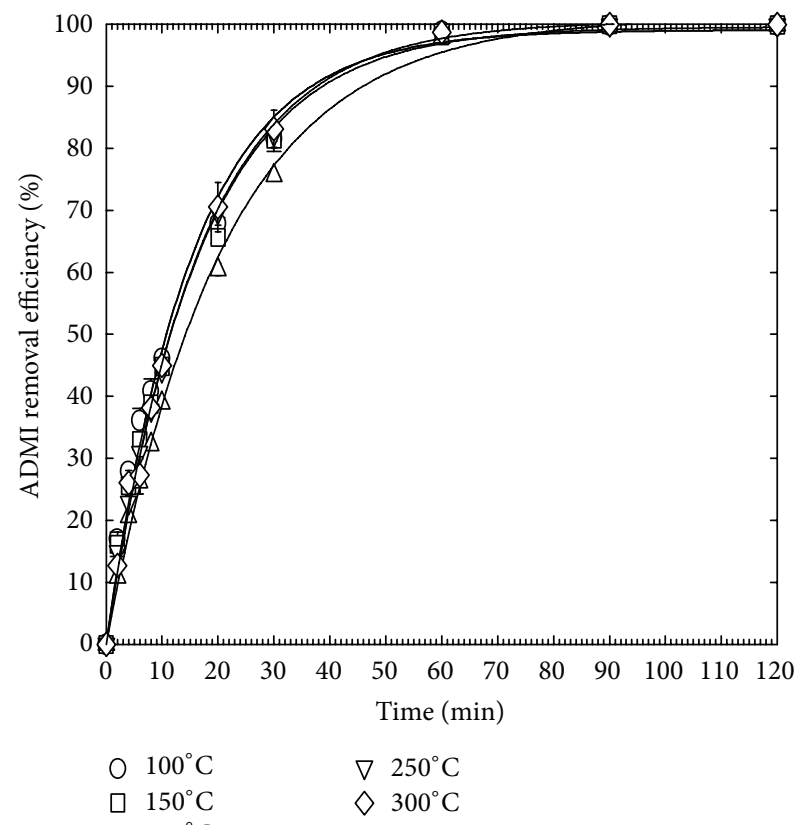

(a)

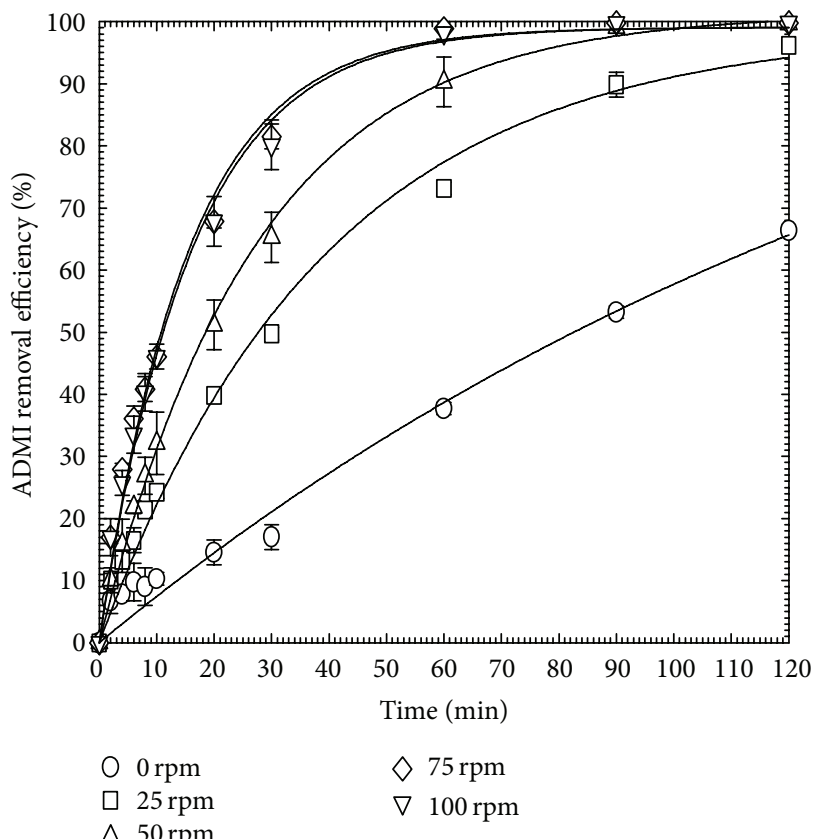

(b)

FIGURE 3: Effect of (a) preparation temperature and (b) mixing speed. The conditions were initial dye concentration of $50 \mathrm{mg} \mathrm{L}^{-1}, \mathrm{ZnO}$ loading of $60 \mathrm{~g} \mathrm{~m}^{-2}$, light intensity of $2.1 \mathrm{~mW} \mathrm{~cm}^{-2}$, and reaction time during $120 \mathrm{~min}$. 


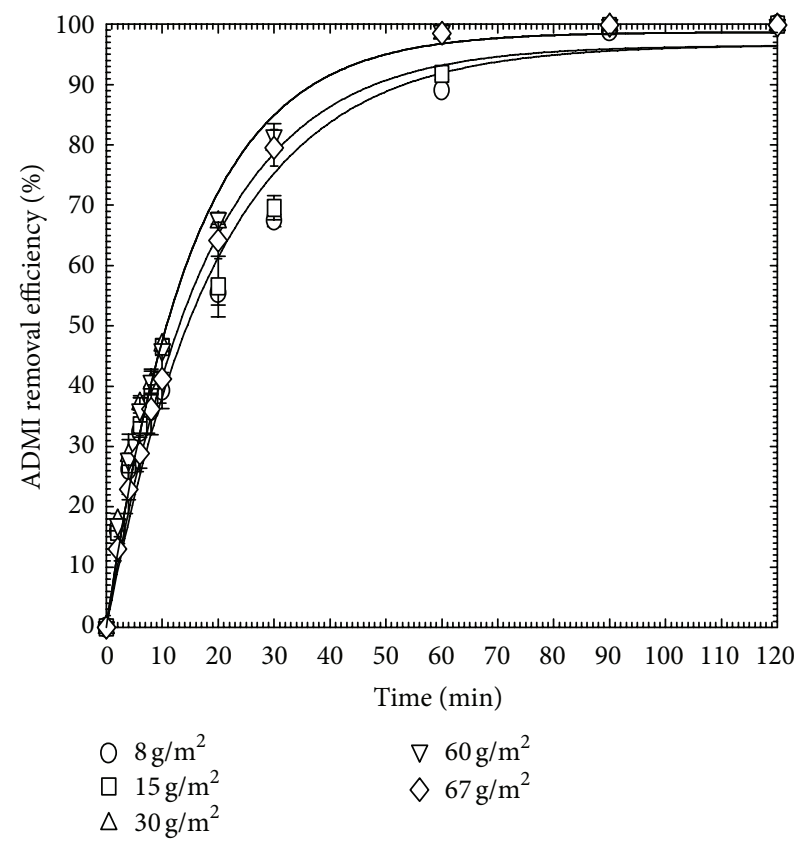

(a)

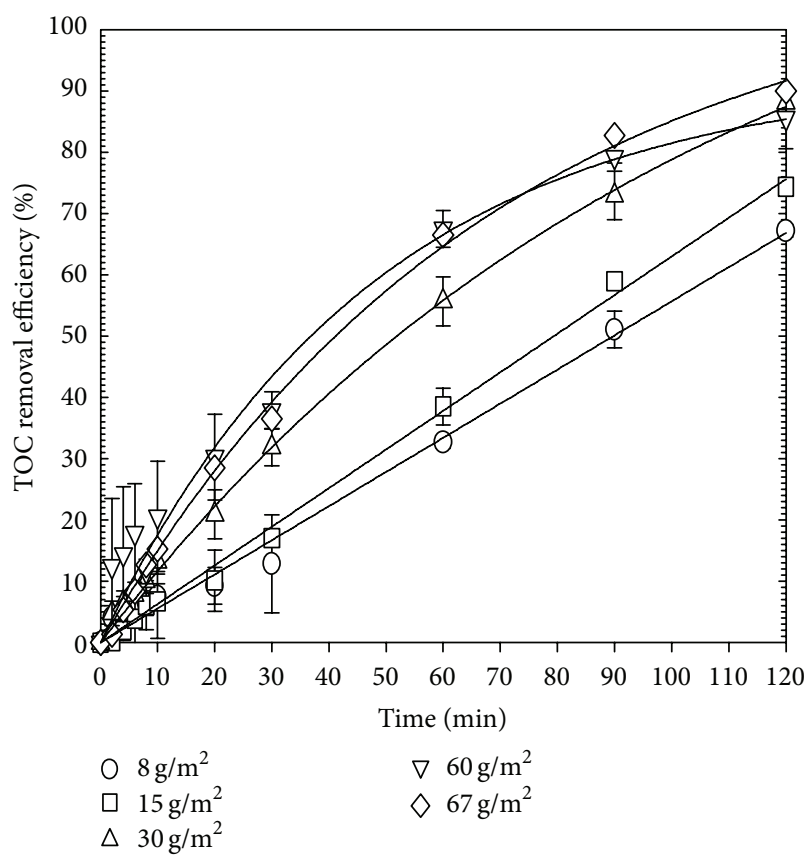

(b)

FIGURE 4: Effect of surface loading of $\mathrm{ZnO}$. The conditions were initial dye concentration of $50 \mathrm{mg} \mathrm{L}^{-1}$, light intensity of $1.05 \mathrm{~mW} \mathrm{~cm}^{-2}$, and reaction time during $120 \mathrm{~min}$.

experimental data. The calculated rate constants (from curve fitting) were $4.44,4.37,3.68,4.32$, and $4.57\left(10^{-2}\right)\left(\mathrm{min}^{-1}\right)$ at $100,150,200,250$, and $300^{\circ} \mathrm{C}$, respectively. The preparation temperature shows neglected effect on OG color removal. Preparation temperature of $150^{\circ} \mathrm{C}$ was chosen as the working condition for its low energy consumption and fast dyeing speed. Figure 3(b) shows the effect of mixing speed on color removal under UV/ZnO photocatalytic system. Mixing speed is definitely an important factor that affects the color removal efficiency. From the results, the higher the mixing speed is, the faster the decolorizing reaction can be obtained. The calculated rate constants (from curve fitting) were 0.60, 2.78, 4.44 , and $4.32\left(10^{-2}\right)\left(\mathrm{min}^{-1}\right)$ at $0,50,75$, and $100 \mathrm{rpm}$, respectively. Therefore, the mixing speed was fixed at $75 \mathrm{rpm}$ for further experimental runs. Since the photocatalytic degradation of OG happened on the surface of $\mathrm{ZnO}$ catalyst, the mass transfer of OG molecules from aqueous solution to the surface of $\mathrm{ZnO}$ catalyst was rather important to affect the reaction rate. The higher mixing speed caused better contact of OG molecules and $\mathrm{ZnO}$ catalyst and presented higher degradation rate of OG. However, when the mixing speed increased to higher than $75 \mathrm{rpm}$, the limited surface of $\mathrm{ZnO}$ cannot provide enough active sites for OG molecules. Therefore, the degradation rate of OG under UV/ZnO system hardly increased while the mixing speed was adjusted to higher than $75 \mathrm{rpm}$.

3.3. Effect of $\mathrm{ZnO}$ Load Dosage. Figure 4(a) shows the removal of color as a function of load dosage of $\mathrm{ZnO}$ under $1.05 \mathrm{~mW} \mathrm{~cm}^{-2}$ of UV irradiation. Results indicated that the color removal increased from 89 to $98.5 \%$ in 60 min when the surface loading of $\mathrm{ZnO}$ particles increased from 8 to $60 \mathrm{~g} \mathrm{~m}^{-2}$. The color removal then decreased from 98.9 to $98.5 \%$ when the surface loading of $\mathrm{ZnO}$ increased from 60 to $67 \mathrm{~g} \mathrm{~m}^{-2}$. An optimal $\mathrm{ZnO}$ loading for color removal occurred at $60 \mathrm{gm}^{-2}$. However, the differences of color removal rate between various $\mathrm{ZnO}$ loads were not significant. The rate constants followed similar trend to percent color removal; the observed rate constants were $0.66,0.67,1.25,2.94$, and $2.98\left(10^{-2} \mathrm{~min}^{-1}\right)$ at surface $\mathrm{ZnO}$ loading dosages of 8, 15, 30, 60, and $67 \mathrm{~g} \mathrm{~m}^{-2}$, respectively. From Figure 4(b), the TOC removal was $67.2 \%$ for $\mathrm{ZnO}$ loading of $8 \mathrm{~g} \mathrm{~m}^{-2}$ and increased up to $88.3 \%$ for $\mathrm{ZnO}$ loading of $60 \mathrm{~g} \mathrm{~m}^{-2}$. Results indicated that the TOC removal was highly affected by various $\mathrm{ZnO}$ loading dosages. On the other hand, $\mathrm{ZnO}$ dosage presented insignificant effect on color removal. To decolorize and mineralize simultaneously, one should choose higher $\mathrm{ZnO}$ loading to both color and TOC removal requirements.

3.4. Effect of UV Light Intensity. Theoretically, the higher the UV light intensity applied to a photocatalytic system, the faster the electron-hole pairs and $\mathrm{OH} \bullet$ free radical form to obtain the higher dye decolorization and mineralization rate. Thus, the rate constant increases by UV intensity increase, while the same $\mathrm{ZnO}$ catalyst surface is loading. Since the photolysis of $\mathrm{ZnO}$ catalyst is enhanced to produce abundant electron-hole pairs and $\mathrm{OH} \bullet$ in the dye solution to be used for decolorization, it is obvious that the more UV intensity employed to the system is, the faster the dye is decolorized. 


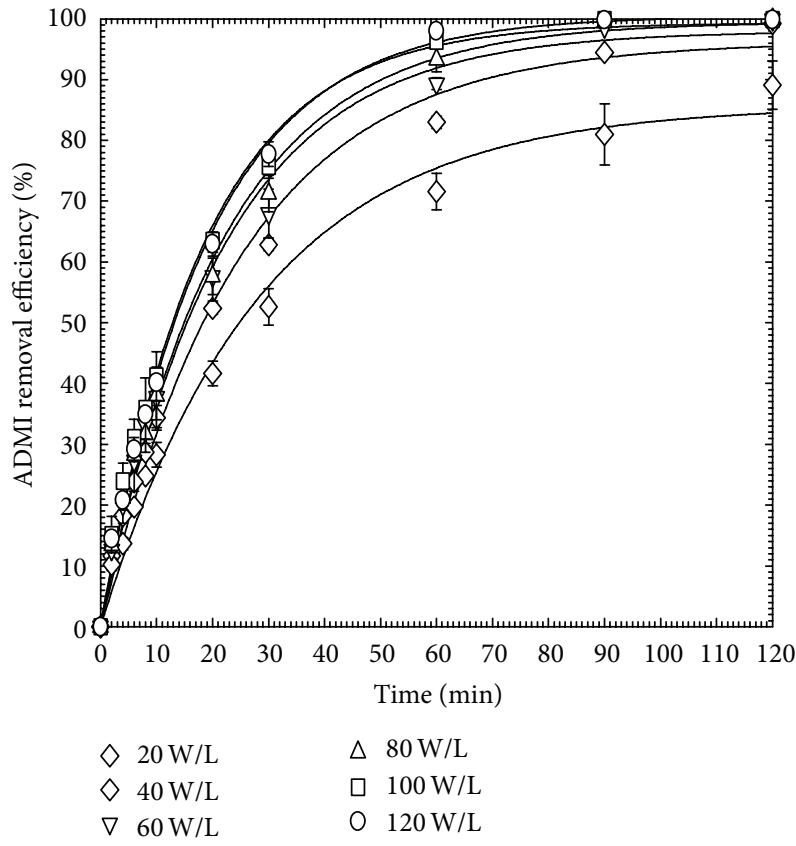

(a)

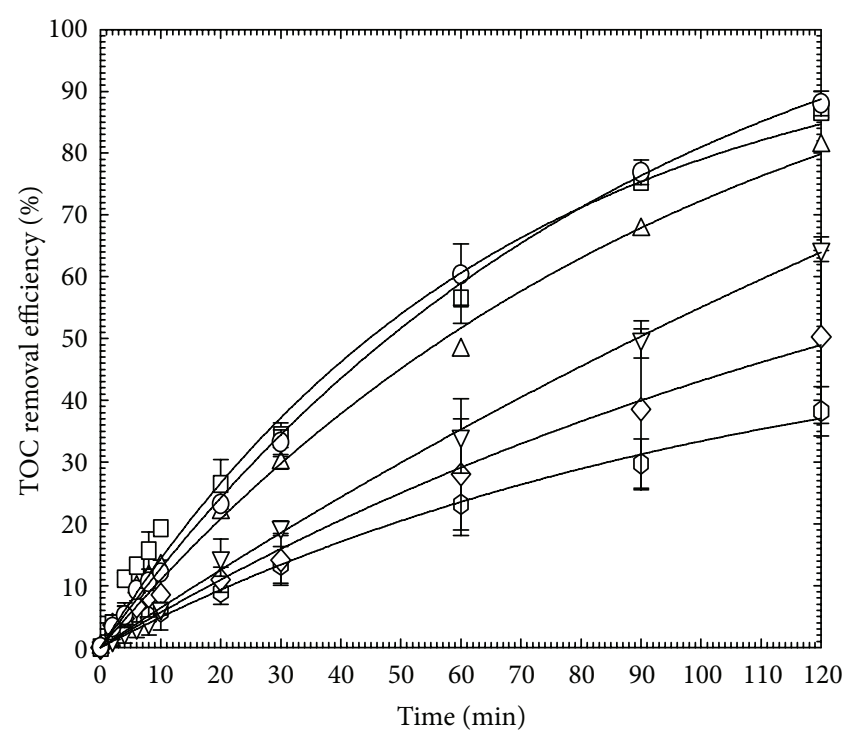
- $20 \mathrm{~W} / \mathrm{L}$
$\diamond 40 \mathrm{~W} / \mathrm{L}$
$\nabla 60 \mathrm{~W} / \mathrm{L}$
$\triangle 80 \mathrm{~W} / \mathrm{L}$
$100 \mathrm{~W} / \mathrm{L}$

FIGURE 5: Effect of UV light intensity on OG (a) decolorization and (b) mineralization by UV/ZnO photocatalytic system. The conditions were initial dye concentration of $50 \mathrm{mg} \mathrm{L}^{-1}, \mathrm{ZnO}$-coated amounts of $60 \mathrm{~g} \mathrm{~m}^{-2}$, and UV light intensity of 20 to $120 \mathrm{~W} \mathrm{~L}^{-1}\left(120 \mathrm{~W} \mathrm{~L}^{-1} \mathrm{measured}^{-}\right.$ as $2.1 \mathrm{~mW} \mathrm{~cm}^{-2}$ ).

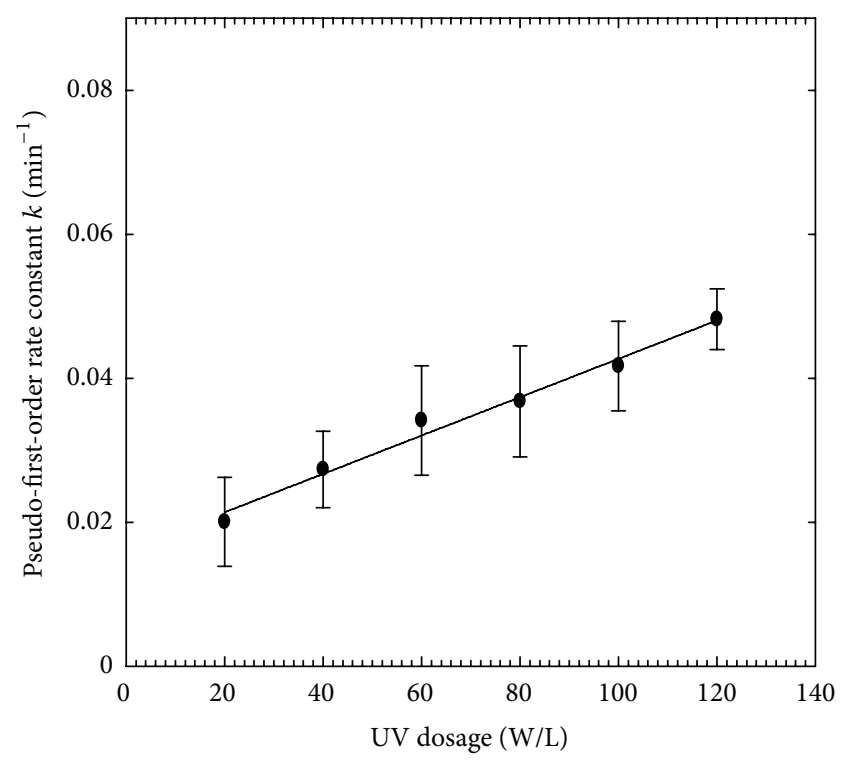

FIGURE 6: Effect of UV light intensity on pseudo-first-order rate constant of OG decolorization by UV/ZnO photocatalytic system. The conditions were the same as in Figure 5.

Figure 5(a) shows the removal of color as a function of UV intensity. Results indicated that the color removal increased from 71.6 to $98.8 \%$ in 60 min when the UV intensity increased from 20 to $120 \mathrm{~W} \mathrm{~L}^{-1}$. The rate constants followed similar trend to percent color removal; the observed rate constants were $2.01,3.42$, and $4.82\left(10^{-2} \mathrm{~min}^{-1}\right)$ at UV intensity
TABLE 2: The first-order reaction rate constant $k\left(10^{2} \mathrm{~min}^{-1}\right)$ for operating parameter of UV intensity and initial concentration.

\begin{tabular}{lccc}
\hline \multicolumn{2}{c}{ Effect of UV intensity } & \multicolumn{2}{c}{ Effect of initial concentration } \\
UV intensity, W L ${ }^{-1}$ & $k$ & Concentration, $\mathrm{mg} \mathrm{L}^{-1}$ & $k$ \\
\hline 20 & 2.00 & 12.5 & 20.14 \\
40 & 2.74 & 18.8 & 16.26 \\
60 & 3.42 & 25 & 17.55 \\
80 & 3.68 & 50 & 5.95 \\
100 & 4.17 & 75 & 5.88 \\
120 & 4.82 & & \\
\hline
\end{tabular}

which increased from 20,60 , and $120 \mathrm{WL}^{-1}$, respectively, as shown in Table 2. Figure 5(b) presents the mineralization of $\mathrm{OG}$ in solution as a function of UV intensity. Results denote that the TOC removal increased from 38.2 to $88.3 \%$ in $120 \mathrm{~min}$ when the UV intensity increased from 20 to $120 \mathrm{~W} \mathrm{~L}^{-1}$. Therefore, applying sufficient UV intensity with $\mathrm{ZnO}$ photocatalyst can fairly mineralize portion of TOC to reach almost total mineralization.

Figure 6 shows the relationship between pseudo-firstorder rate constants and UV light intensity that a linear relationship can be obtained. This presents that the UV light intensity is an important operating parameter which linearly affects the decolorization of OG under $\mathrm{UV} / \mathrm{ZnO}$ photocatalytic system. In this work, the maximum UV light intensity was $120 \mathrm{~W} \mathrm{~L}^{-1}$, which can be transferred into photo 


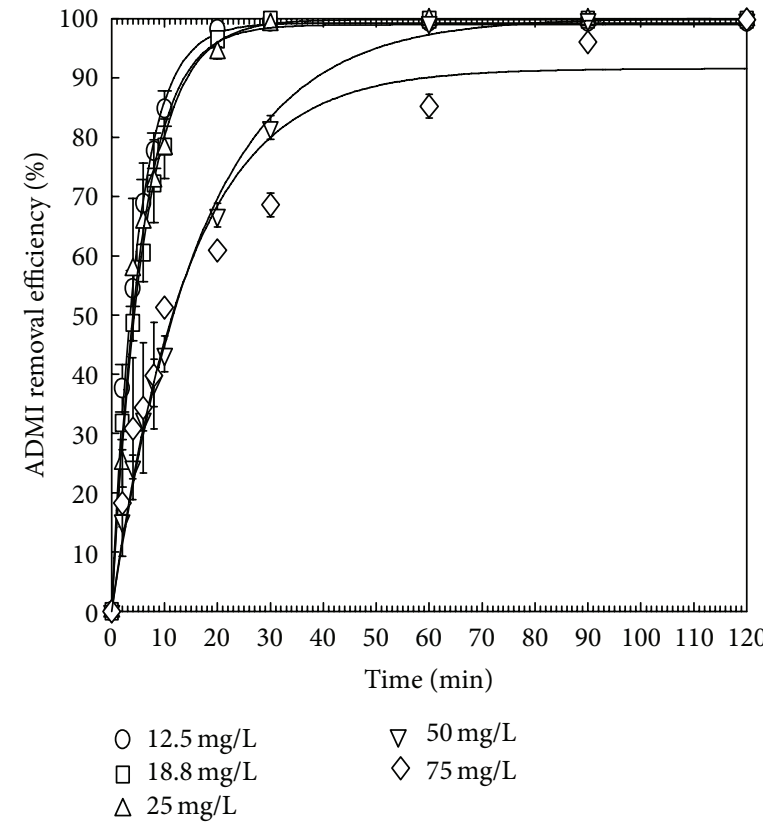

(a)

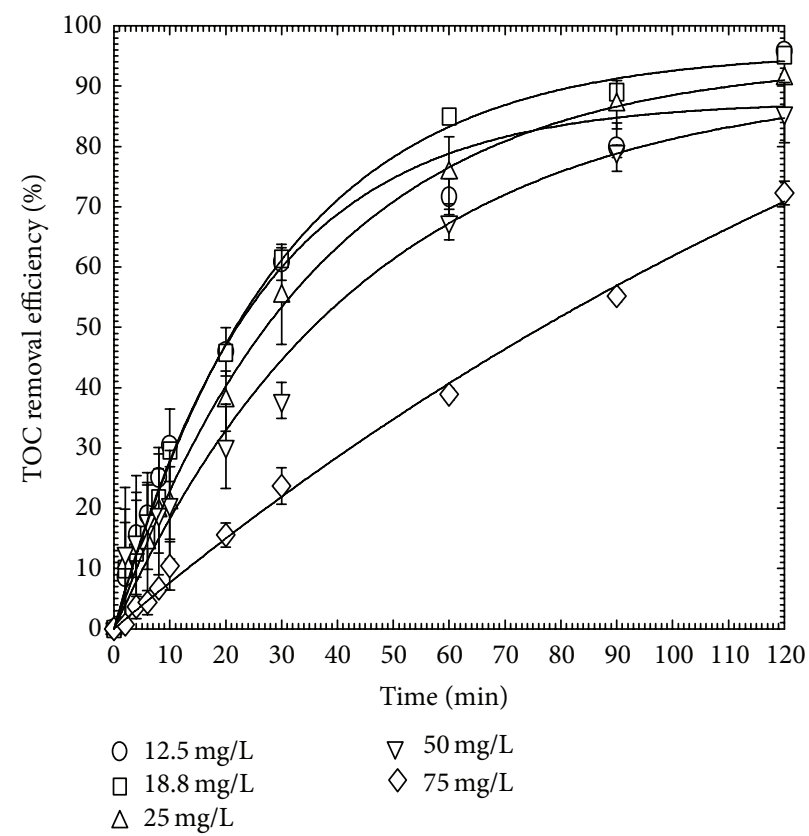

(b)

FIGURE 7: Effect of initial concentration on (a) ADMI color and (b) TOC removal. The conditions were $\mathrm{ZnO}$-coated amounts of 60 gm ${ }^{-2}$, light intensity of $2.1 \mathrm{~mW} \mathrm{~cm}^{-2}$, and reaction time during $0-120 \mathrm{~min}$.

flux density as $2.1 \mathrm{~mW} \mathrm{~cm}^{-2}$. From previous studies, photocatalytic reaction rate constant is linearly increased with UV intensity while operating in low region of UV intensity, that is, between 0 and $20 \mathrm{~mW} \mathrm{~cm}^{-2}[17,20]$. The degradation of OG under UV/ZnO system was major caused by formation of $\mathrm{OH} \bullet$ free radicals. From a previous study by Xiang et al., $\mathrm{ZnO}$ had the third highest formation rate of $\mathrm{OH} \bullet$ free radicals following P25 and anatase $\mathrm{TiO}_{2}$ [26]. Under higher UV irradiation intensity, the formation rate of $\mathrm{OH} \bullet$ free radicals was higher. This caused faster degradation reaction of OG under UV/ZnO system.

3.5. Effect of Dye Initial Concentration. To present the validity of $\mathrm{L}-\mathrm{H}$ model on our CCFL/ZnO system, the effect of initial dye concentrations on the photodegradation of azo OG dye was studied at initial concentrations of $12.5-75 \mathrm{mg} \mathrm{L}^{-1}$, $\mathrm{ZnO}$ dosage of $60 \mathrm{gm}^{-2}$, and 6 CCFL lamps for a period of $120 \mathrm{~min}$ in the closed reactor. Figure 7 shows results of dye photodegradation as a function of reaction time at various initial dye concentrations. Results indicated that the rate of dye removal decreased from 20.1 to $5.95\left(10^{-2} \mathrm{~min}^{-1}\right)$ when the initial dye concentration was increased from 12.5 to $50 \mathrm{mg} \mathrm{L}^{-1}$, as shown in Table 2. The rate constant then remained constant and independent of the dye concentration as the initial dye concentration increased to greater than $50 \mathrm{mg} \mathrm{L}^{-1}$. This is typical Langmuir-Hinshelwood (L-H) reaction kinetics which is generally capable of modeling UV/ZnO photocatalytic oxidation process [27-30]. According to the
$\mathrm{L}-\mathrm{H}$ reaction kinetics, the rate of dye degradation can be described by the following equation:

$$
r=\frac{d C}{d t}=\frac{k K_{A} C}{1+K_{A} C},
$$

where $r$ is the degradation rate of dye $\left(\mathrm{mg} \mathrm{L}^{-1} \mathrm{~min}^{-1}\right)$ and $k$, $K_{A}$, and $C$ are the rate constant $\left(\mathrm{mg} \mathrm{L}^{-1} \mathrm{~min}^{-1}\right)$, equilibrium adsorption constant $\left(\mathrm{L} \mathrm{mg}^{-1}\right)$, and residual dye concentration $\left(\mathrm{mg} \mathrm{L}^{-1}\right)$, respectively. According to the above equation, at high dye concentration, that is, $1 \ll K C$, the rate equation is

$$
r=k
$$

Likewise, at low dye concentration, that is, $1 \gg K C$, the above equation (2) becomes

$$
r=k K_{A} C .
$$

That is, as the initial concentration increases, the reaction no longer follows the first-order expression; it rather becomes independent of the dye concentration as shown in (3). By rearranging (2), one has

$$
\frac{1}{r_{0}}=\frac{1}{k K_{A}} \times \frac{1}{C_{0}}+\frac{1}{k}
$$

where $r_{0}$ and $C_{0}$ are the initial rate $\left(\mathrm{mg} \mathrm{L}^{-1} \mathrm{~min}^{-1}\right)$ and initial dye concentration $\left(\mathrm{mg} \mathrm{L}^{-1}\right)$, respectively. A plot of the reciprocals of initial rate and initial concentration yields the rate 


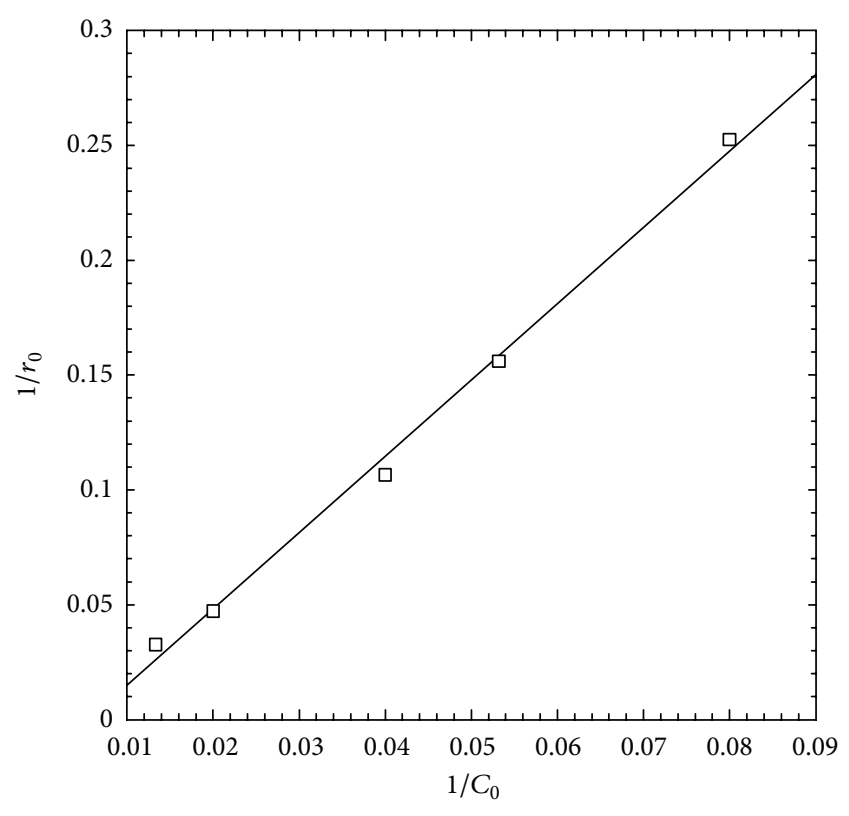

FIGURE 8: Langmuir-Hinshelwood kinetic model ( $\mathrm{ZnO}$ loading dosage of $60 \mathrm{~g} \mathrm{~m}^{-2}$ with light intensity of $2.1 \mathrm{~mW} \mathrm{~cm}^{-2}$ ).

constant, $k$, and the adsorption constant, $K$ (Figure 8 ). The initial rate $r_{0}$ was calculated by the first 2 min of Figure 7 with $\mathrm{ZnO}$ loading dosage of $60 \mathrm{~g} \mathrm{~m}^{-2}$. From the slope $\left(1 / k_{A}\right)$ and the intercept $(1 / k)$ of Figure 8 , the calculated $k$ and $K_{A}$ were $54.35 \mathrm{mg} \mathrm{L}^{-1} \mathrm{~min}^{-1}$ and $0.0055 \mathrm{mg}^{-1}$ for $\mathrm{ZnO}$ loading dosage of $60 \mathrm{~g} \mathrm{~m}^{-2}$. The rate constants $(k)$ obtained in this work of $54.35 \mathrm{mg} \mathrm{L}^{-1} \mathrm{~min}^{-1}$ were higher than that of previous works [27-30] such as $1.66,1.67,0.95$, and $0.17 \mathrm{mg} \mathrm{L}^{-1} \mathrm{~min}^{-1}$ for various dyes such as direct red 16, Remazol Black 5, Procion Red MX-5B, and indigo carmine, respectively. Similarly, the equilibrium adsorption constants $\left(K_{A}\right)$ of $0.0055 \mathrm{~L} \mathrm{mg}^{-1}$ from this work were in the range of previous studies, such as $0.0093,0.072,0.071$, and $0.78 \mathrm{~L} \mathrm{mg}^{-1}$, for various dyes as above. The results indicate that the photocatalytic degradation of Orange $\mathrm{G}$ by $\mathrm{CCFL} / \mathrm{ZnO}$ process followed the Langmuir-Hinshelwood kinetic model with fairly good prediction of $r^{2}=0.996$.

3.6. Effect of $p H$. The effect of $\mathrm{pH}$ on the degradation of azo dye was conducted by adjusting the initial $\mathrm{pH}$ value of 5.0 to the range of 2 to 11 using $\mathrm{HCl}$ and/or $\mathrm{NaOH}$ with initial OG dye concentration of $50 \mathrm{mg} \mathrm{L}^{-1}$ and $60 \mathrm{~g} \mathrm{~m}^{-2}$ of $\mathrm{ZnO}$ dosage. Figure 9(a) shows OG dye removal as a function of time at various $\mathrm{pH}$ values. Results indicated that, at original $\mathrm{pH}$, the color removal reached $78.5 \%$ in $30 \mathrm{~min}$ of photocatalytic reaction. At acidic $\mathrm{pH}$ of 2 and 3, the color removal rates of 76.7 and $76.1 \%$ were obtained, respectively. This implies that acidic $\mathrm{pH}$ provides no benefit for $\mathrm{OG}$ decolorization under UV/ZnO system. On the other hand, at alkaline $\mathrm{pH}$ of 11 , the color removal rate sharply increased up to $95.6 \%$. Figure 9(b) shows the TOC removal as a function of time at various $\mathrm{pH}$ values. Results indicated that, at original $\mathrm{pH}$, the TOC removal reached $88.3 \%$ in 120 min of photocatalytic
TABLE 3: The first-order reaction rate constant $k\left(10^{2} \mathrm{~min}^{-1}\right)$ for operating parameter of $\mathrm{pH}$ and duration.

\begin{tabular}{lccc}
\hline & Effect of initial $\mathrm{pH}$ & \multicolumn{2}{c}{ Duration test } \\
$\mathrm{pH}$ & $k$ & Cycle & $k$ \\
\hline 2 & 3.74 & 1 & 4.41 \\
3 & 3.74 & 2 & 3.95 \\
5 & 4.18 & 3 & 3.44 \\
9 & 3.69 & 4 & 3.33 \\
11 & 9.15 & 5 & 3.24 \\
& & 6 & 3.11 \\
& & 7 & 2.84 \\
& & 8 & 2.35 \\
& & 9 & 2.31 \\
& & 10 & 2.31 \\
\hline
\end{tabular}

reaction. At acidic $\mathrm{pH}$ of 2 and 3, the color removal rates of 70.1 and $82.8 \%$ were obtained, respectively. At alkaline $\mathrm{pH}$ of 11 , TOC removal rate was $87.8 \%$. This implies that the TOC removal rate is rather stable in the range of 82.8-88.3 for $\mathrm{pH}$ range 3-11. And for $\mathrm{pH} 2$, an extremely acidic condition, the TOC removal dropped from $12-18 \%$ to $70.1 \%$. Extremely acidic $\mathrm{pH}$ has disadvantage for TOC removal under $\mathrm{UV} / \mathrm{ZnO}$ system for $\mathrm{OG}$ solution, since $0.1 \mathrm{~N} \mathrm{HCl}$ solution was used to adjust solution $\mathrm{pH}$ value to $2-3$. At this operating condition, there were abundant amounts of high concentration chloride ions in the solution to play the role of free radical scavenger. Chloride ions competed with OG molecules to consume free radicals. Therefore, the decolorization and mineralization rate of $\mathrm{OG}$ by $\mathrm{UV} / \mathrm{ZnO}$ system decreased. The observed rate constants for various $\mathrm{pH}$ values were summarized in Table 3.

3.7. The Product Analysis by FTIR and IC. The change of functional groups of azo dye after photocatalytic treatment was surveyed. The initial dye concentration was $50 \mathrm{mg} \mathrm{L}^{-1}$ and was treated with a $\mathrm{ZnO}$ dosage of $60 \mathrm{~g} \mathrm{~m}^{-2}$ and reaction time of $120 \mathrm{~min}$. The scan spectra (Figure 10(a)) for the functional groups are $\mathrm{SO}_{3} \mathrm{Na}$ of $1150 \sim 1250 \mathrm{~cm}^{-1}, \mathrm{~N}=\mathrm{N}$ of 1426 , 1462 and $1495 \mathrm{~cm}^{-1}, \mathrm{C}=\mathrm{O}$ of $1690 \sim 1760 \mathrm{~cm}^{-1}$, and $\mathrm{C}-\mathrm{H}$ and $\mathrm{N}-\mathrm{H}$ of $3300 \sim 3500 \mathrm{~cm}^{-1}$. After the photocatalytic oxidation (Figure 10(b)), a new double bond $\mathrm{C}=\mathrm{O}$ at $1637 \mathrm{~cm}^{-1}$ was produced. Meanwhile, the $\mathrm{N}=\mathrm{N}$ from dye at 1426, 1463, and $1496 \mathrm{~cm}^{-1}$ disappeared due to attack by the hydroxyl radicals that cleaved the double bond $\mathrm{N}=\mathrm{N}$. Accordingly, the dye molecule was degraded and decolorized. The ions such as sulfate, chloride, nitrite, and nitrate were determined. Figure 11(a) shows that the major ion concentration of sulfate significantly increased to $16 \mathrm{mg} \mathrm{L}^{-1}$ over time. The chloride ion produced due to the impurity of OG dye was as low as $1.5 \mathrm{mg} \mathrm{L}^{-1}$. The nitrate ion concentration was about from 1.0 to $4.5 \mathrm{mg} \mathrm{L}^{-1}$, and nitrite concentration was less than $0.5 \mathrm{mg} \mathrm{L}^{-1}$ as shown in Figure 11(b).

3.8. Application Duration. The steel mesh supported $\mathrm{ZnO}$ catalyst was used repeatedly to treat the OG solution. 


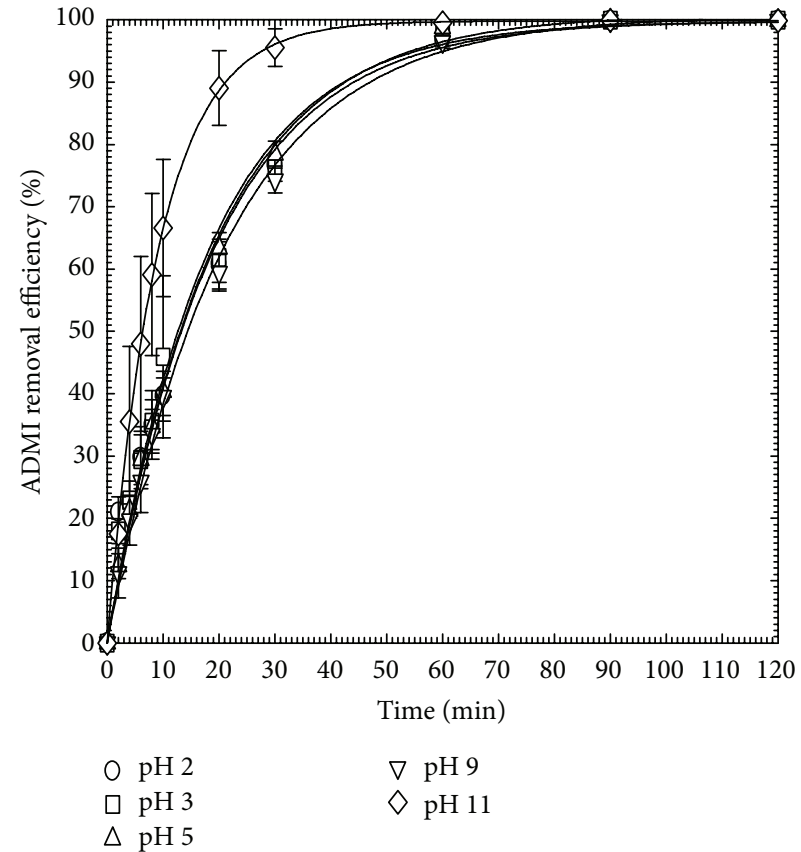

(a)

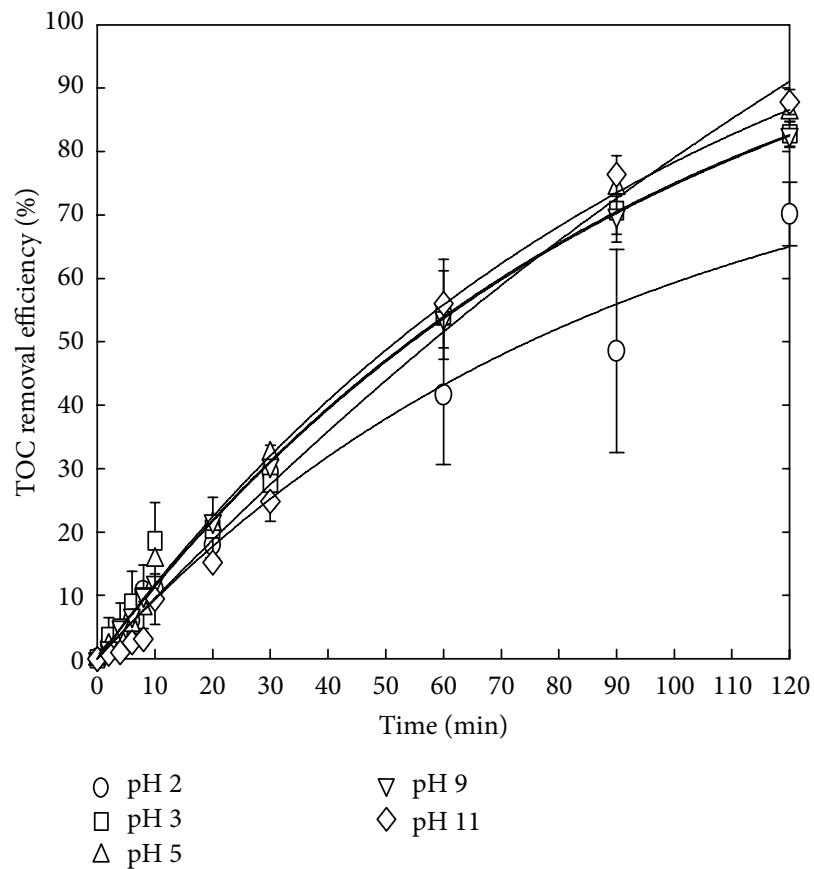

(b)

FIGURE 9: Effect of initial $\mathrm{pH}$ on (a) decolorization and (b) mineralization of OG under UV/ZnO system. The conditions were initial dye concentration of $50 \mathrm{mg} \mathrm{L}^{-1}, \mathrm{ZnO}$-coated amounts of $60 \mathrm{~g} \mathrm{~m}^{-2}$, light intensity of $2.1 \mathrm{~mW} \mathrm{~cm}^{-2}$, and reaction time during $120 \mathrm{~min}$.

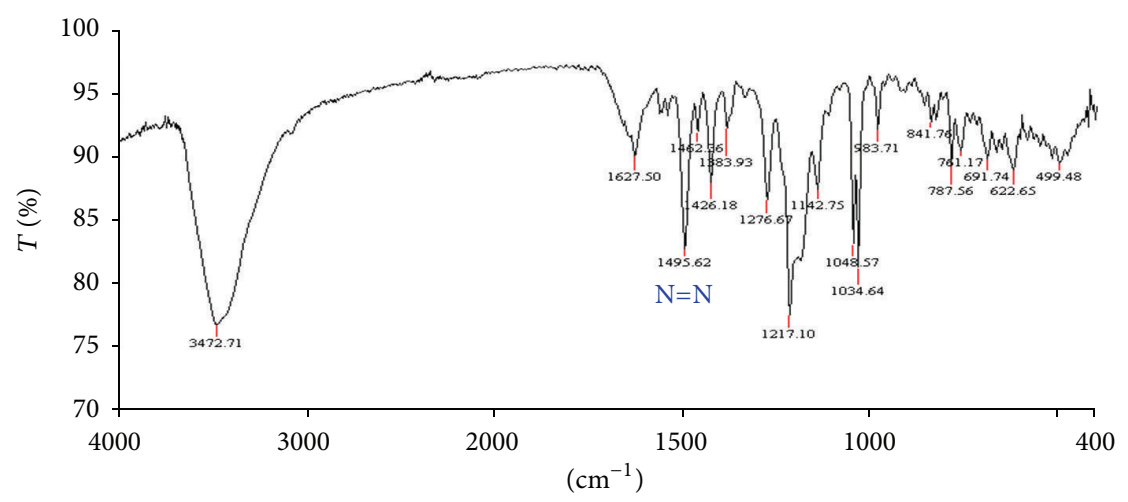

(a)

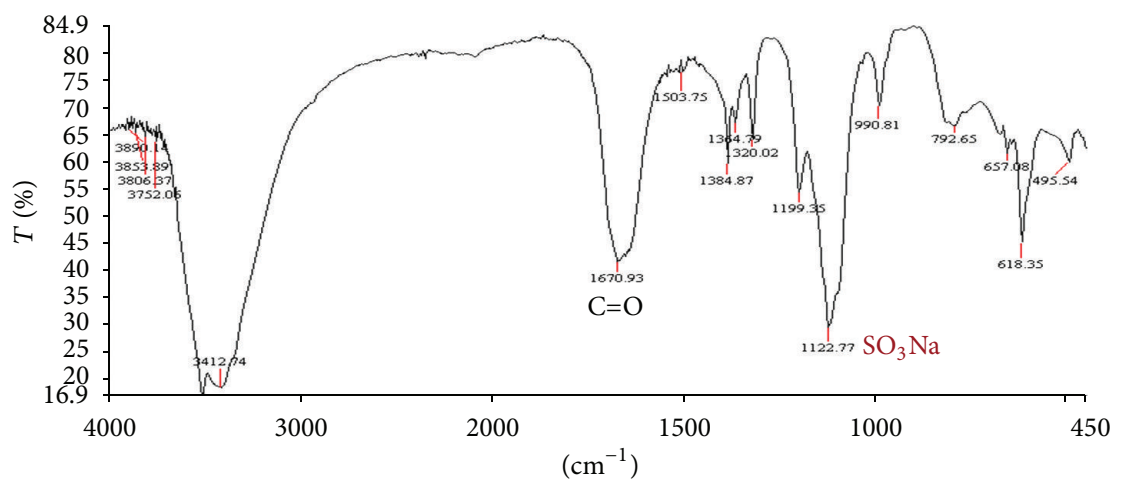

(b)

FIgURE 10: FTIR spectra for OG decolorization and demineralization (a) before and (b) after UV/ZnO photocatalytic degradation. The operating conditions were the same as in Figure 2. 


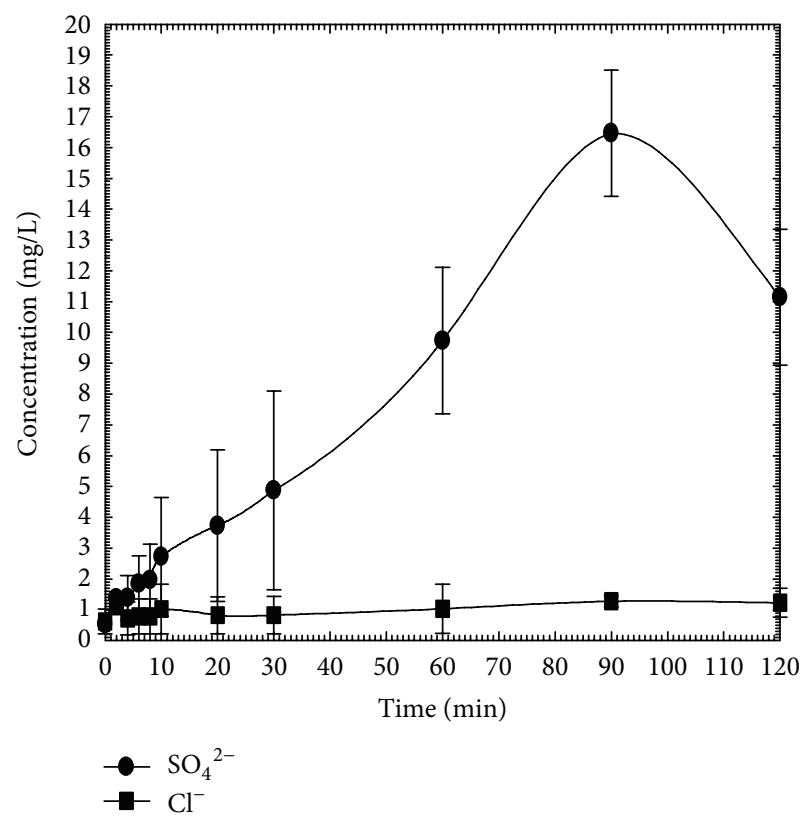

(a)

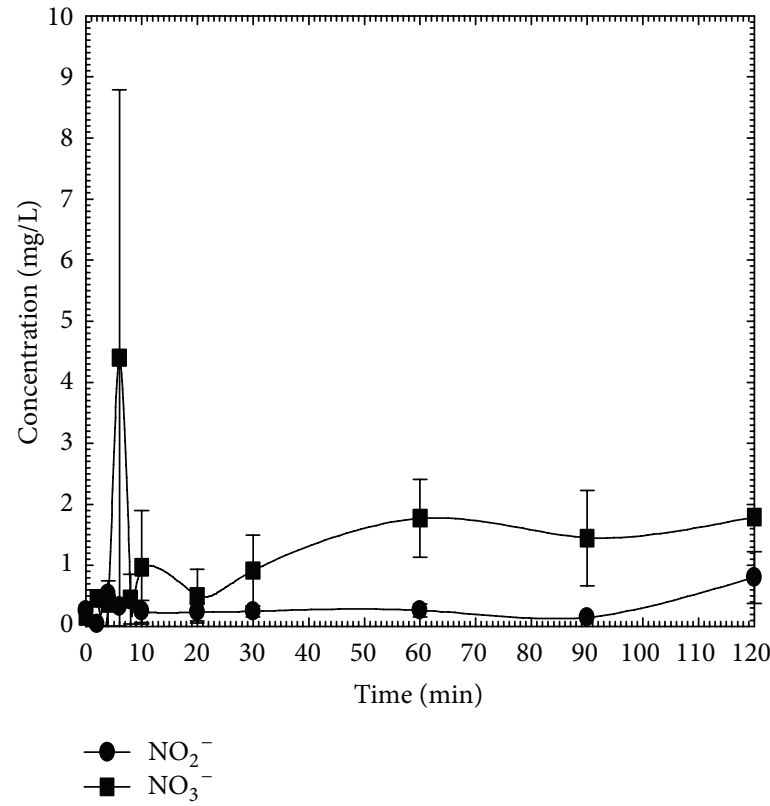

(b)

FIgURE 11: The product analysis by IC, (a) $\mathrm{SO}_{4}{ }^{2-}$ and $\mathrm{Cl}^{-}$, and (b) $\mathrm{NO}_{3}{ }^{-}$and $\mathrm{NO}_{2}{ }^{-}$. The conditions were initial dye concentration of $50 \mathrm{mg} \mathrm{L}{ }^{-1}$, $\mathrm{ZnO}$-coated amounts of $60 \mathrm{~g} \mathrm{~m}^{-2}$, and light intensity of $2.1 \mathrm{~mW} \mathrm{~cm}^{-2}$ at $120 \mathrm{~min}$.

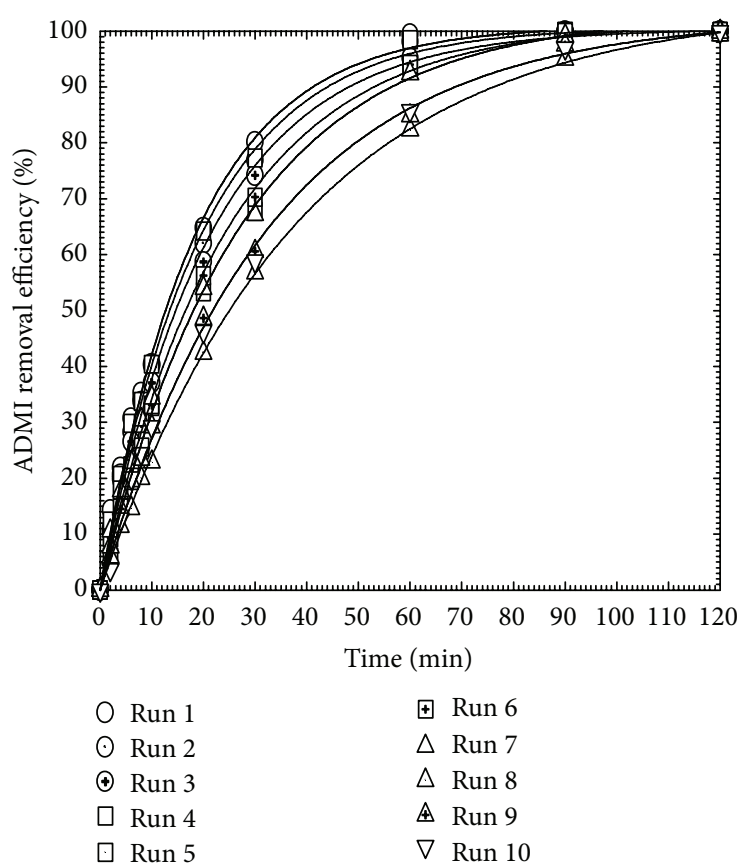

(a)

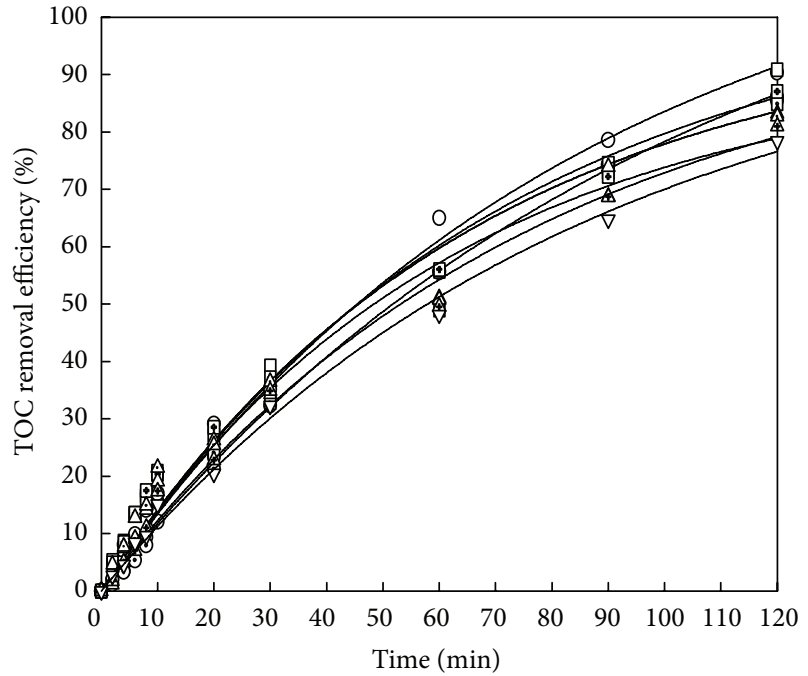
O Run 1
○ Run 2
由 Run 6
$\odot$ Run 3
Run 7
$\square$ Run 4
$\triangle$ Run 8
A Run 9
$\nabla$ Run 10

(b)

FIgURE 12: Duration test on (a) color and (b) TOC removal. The conditions were initial dye concentration of $50 \mathrm{mg} \mathrm{L}^{-1}, \mathrm{ZnO}^{-c o a t e d ~ a m o u n t s}$ of $60 \mathrm{gm}^{-2}$, light intensity of $2.1 \mathrm{~mW} \mathrm{~cm}^{-2}$, and reaction time during $120 \mathrm{~min}$.

Figure 12 shows the system performance over 10 cycles. Results indicated that, although the rate of OG degradation decreased as the reuse cycle of catalyst increased, the total amount of dye removal remained relatively unchanged at $100 \%$ in the treatment time range of 100-120 min, however.
Instead of ADMI color, the TOC removal decreased from 90 to $78 \%$ after ten experimental runs. In the meantime, there was nearly neglected loss $(0.04 \%)$ of $\mathrm{ZnO}$ in each operation even after 10 cycles according to the solution $\mathrm{Zn}$ concentration analysis by atomic absorption. The observed 
rate constants declined with more reuse cycles as shown in Table 3 from 0.0441 to $0.0231 \mathrm{~min}^{-1}$, however. This can be attributed to potential surface poisoning of the photocatalyst, $\mathrm{ZnO}$, due to adsorption of reaction products.

\section{Conclusions}

Steel mesh supported $\mathrm{ZnO}$ catalyst illuminated with cold cathode fluorescent light (CCFL) UV was effective in the removal of ADMI color and TOC from the OG azo dye solution. Preparation temperature showed insignificant effect on color and TOC removal. An optimal $\mathrm{ZnO}$ surface loading or dosage of $60 \mathrm{~g} \mathrm{~m}^{-2}$ exhibited the highest color removal as well as the fastest rate; further increase in surface $\mathrm{ZnO}$ loading had no benefit in increasing the color removal, however. An alkaline $\mathrm{pH}$ of 11 had the best photocatalytic oxidation rate; the rate of color removal was stable in the range from $\mathrm{pH} 3$ to 9. At $\mathrm{pH} 2$, the TOC removal rate was the lowest among all $\mathrm{pH}$ range. The rate of color removal decreased with initial dye concentration as was expected by the LangmuirHinshelwood kinetics. The rate of color removal increased with UV intensity linearly. The $\mathrm{ZnO}$-coated steel mesh can be repeatedly used over 10 cycles without significant loss of catalyst mass; the percent dye removal remained close to $100 \%$ in 10 cycles except for about 50\% decrease in reaction rate constants apparently due to possible surface poisoning. Based on FTIR analysis, there was decrease of $\mathrm{N}=\mathrm{N}$ bonding which indicated chemical transformation of the dye OG compound. Results of analyzing the inorganic byproducts revealed that sulfate production was predominant; nitrite and nitrate were produced at minor quantities.

\section{Acknowledgments}

The authors appreciate the research funding granted by the Taiwan National Science Foundation (NSC 98-2221-E-241006-MY3) as well as the analysis by NSC Instrumental Center of the National Chung Hsing University and the National Tsing Hua University.

\section{References}

[1] N. H. Ince and D. T. Gönenç, "Treatability of a textile azo dye by $\mathrm{UV} / \mathrm{H}_{2} \mathrm{O}_{2}$," Environmental Technology, vol. 18, no. 2, pp. 179$185,1997$.

[2] U. Pagga and D. Brown, "The degradation of dyestuffs: part II. Behaviour of dyestuffs in aerobic biodegradation tests," Chemosphere, vol. 15, no. 4, pp. 479-491, 1986.

[3] M. A. Brown and S. C. DeVito, "Predicting azo dye toxicity," Critical Reviews in Environmental Science and Technology, vol. 23, no. 3, pp. 249-324, 1993.

[4] H.-Y. Shu, C.-R. Huang, and M.-C. Chang, "Decolorization of mono-azo dyes in wastewater by advanced oxidation process: a case study of acid red 1 and acid yellow 23," Chemosphere, vol. 29, no. 12, pp. 2597-2607, 1994.

[5] C. M. Kao, M. S. Chou, W. L. Fang, B. W. Liu, and B. R. Huang, "Regulating colored textile wastewater by $3 / 31$ wavelength admi methods in Taiwan," Chemosphere, vol. 44, no. 5, pp. 1055-1063, 2001.
[6] H.-Y. Shu and C.-R. Huang, "Degradation of commercial azo dyes in water using ozonation and UV enhanced ozonation process," Chemosphere, vol. 31, no. 8, pp. 3813-3825, 1995.

[7] C. Galindo and A. Kalt, "UV- $\mathrm{H}_{2} \mathrm{O}_{2}$ oxidation of monoazo dyes in aqueous media: a kinetic study," Dyes and Pigments, vol. 40, no. 1, pp. 27-35, 1999.

[8] M. Neamtu, I. Siminiceanu, A. Yediler, and A. Kettrup, "Kinetics of decolorization and mineralization of reactive azo dyes in aqueous solution by the $\mathrm{UV} / \mathrm{H}_{2} \mathrm{O}_{2}$ oxidation," Dyes and Pigments, vol. 53, pp. 93-99, 2002.

[9] R. Venkatadri and R. W. Peters, "Chemical oxidation technologies: ultraviolet light/hydrogen peroxide, Fenton's reagent, and titanium dioxide-assisted photocatalysis," Hazardous Waste and Hazardous Materials, vol. 10, no. 2, pp. 107-149, 1993.

[10] H.-Y. Shu, M.-C. Chang, and H.-J. Fan, "Decolorization of azo dye acid black 1 by the $\mathrm{UV} / \mathrm{H}_{2} \mathrm{O}_{2}$ process and optimization of operating parameters," Journal of Hazardous Materials, vol. 113, no. 1-3, pp. 201-208, 2004.

[11] H.-Y. Shu, M.-C. Chang, and H.-J. Fan, "Effects of gap size and UV dosage on decolorization of C.I. Acid Blue 113 wastewater in the UV/ $\mathrm{H}_{2} \mathrm{O}_{2}$ process," Journal of Hazardous Materials, vol. 118, no. 1-3, pp. 205-211, 2005.

[12] E. Rodríguez, R. Peche, J. M. Merino, and L. M. Camarero, "Decoloring of aqueous solutions of indigocarmine dye in an acid medium by $\mathrm{H}_{2} \mathrm{O}_{2}$ /UV advanced oxidation," Environmental Engineering Science, vol. 24, no. 3, pp. 363-371, 2007.

[13] H.-Y. Shu and M.-C. Chang, "Decolorization effects of six azo dyes by $\mathrm{O}_{3}, \mathrm{UV} / \mathrm{O}_{3}$ and $\mathrm{UV} / \mathrm{H}_{2} \mathrm{O}_{2}$ processes," Dyes and Pigments, vol. 65, no. 1, pp. 25-31, 2005.

[14] C.-H. Wu and H.-Y. Ng, "Degradation of C.I. Reactive Red 2 (RR2) using ozone-based systems: comparisons of decolorization efficiency and power consumption," Journal of Hazardous Materials, vol. 152, no. 1, pp. 120-127, 2008.

[15] T.-H. Kim, C. Park, J. Yang, and S. Kim, "Comparison of disperse and reactive dye removals by chemical coagulation and Fenton oxidation," Journal of Hazardous Materials, vol. 112, no. 1-2, pp. 95-103, 2004.

[16] F. Ay, E. C. Catalkaya, and F. Kargi, "Advanced oxidation of direct red (DR 28) by fenton treatment," Environmental Engineering Science, vol. 25, no. 10, pp. 1455-1462, 2008.

[17] M. A. Behnajady, N. Modirshahla, and R. Hamzavi, "Kinetic study on photocatalytic degradation of C.I. Acid Yellow 23 by $\mathrm{ZnO}$ photocatalyst," Journal of Hazardous Materials, vol. 133, no. 1-3, pp. 226-232, 2006.

[18] S. Chakrabarti and B. K. Dutta, "Photocatalytic degradation of model textile dyes in wastewater using $\mathrm{ZnO}$ as semiconductor catalyst," Journal of Hazardous Materials, vol. 112, no. 3, pp. 269278, 2004.

[19] N. Daneshvar, M. H. Rasoulifard, A. R. Khataee, and F. Hosseinzadeh, "Removal of C.I. Acid Orange 7 from aqueous solution by UV irradiation in the presence of $\mathrm{ZnO}$ nanopowder," Journal of Hazardous Materials, vol. 143, no. 1-2, pp. 95-101, 2007.

[20] J. Yu and X. Yu, "Hydrothermal synthesis and photocatalytic activity of zinc oxide hollow spheres," Environmental Science and Technology, vol. 42, no. 13, pp. 4902-4907, 2008.

[21] S. Liu, C. Li, J. Yu, and Q. Xiang, "Improved visible-light photocatalytic activity of porous carbon self-doped $\mathrm{ZnO}$ nanosheetassembled flowers," CrystEngComm, vol. 13, no. 7, pp. 2533-2541, 2011.

[22] M. A. Behnajady, N. Modirshahla, N. Daneshvar, and M. Rabbani, "Photocatalytic degradation of C.I. Acid Red 27 by 
immobilized $\mathrm{ZnO}$ on glass plates in continuous-mode," Journal of Hazardous Materials, vol. 140, no. 1-2, pp. 257-263, 2007.

[23] V. Koutantou, M. Kostadima, and E. Chatzisymeon, "Solar photocatalytic decomposition of estrogens over immobilized zinc oxide," Catalysis Today, vol. 209, pp. 66-73, 2013.

[24] A. Zacharakis, E. Chatzisymeon, V. Binas, Z. Frontistis, D. Venieri, and D. Mantzavinos, "Solar photocatalytica degradation of bisphenol A on immobilized $\mathrm{ZnO}$ or $\mathrm{TiO}_{2}$," International Journal of Photoenergy, vol. 2013, Article ID 570587, 9 pages, 2013.

[25] M. C. Chang, C. P. Huang, H. Y. Shu, and Y. C. Chang, "A new photocatalytic system using steel mesh and cold cathode fluorescent light for the decolorization of azo dye orange G," International Journal of Photoenergy, vol. 2012, Article ID 303961, 9 pages, 2012.

[26] Q. Xiang, J. Yu, and P. K. Wong, "Quantitative characterization of hydroxyl radicals produced by various photocatalysts," Journal of Colloid and Interface Science, vol. 357, no. 1, pp. 163-167, 2011.

[27] T. Aarthi, P. Narahari, and G. Madras, "Photocatalytic degradation of Azure and Sudan dyes using nano $\mathrm{TiO}_{2}$," Journal of Hazardous Materials, vol. 149, no. 3, pp. 725-734, 2007.

[28] K. Sahel, N. Perol, H. Chermette, C. Bordes, Z. Derriche, and C. Guillard, "Photocatalytic decolorization of Remazol Black 5 (RB5) and Procion Red MX-5B-Isotherm of adsorption, kinetic of decolorization and mineralization," Applied Catalysis B, vol. 77, no. 1-2, pp. 100-109, 2007.

[29] N. Barka, A. Assabbane, A. Nounah, and Y. A. Ichou, "Photocatalytic degradation of indigo carmine in aqueous solution by $\mathrm{TiO}_{2}$-coated non-woven fibres," Journal of Hazardous Materials, vol. 152, no. 3, pp. 1054-1059, 2008.

[30] J. Saien, M. Asgari, A. R. Soleymani, and N. Taghavinia, "Photocatalytic decomposition of direct red 16 and kinetics analysis in a conic body packed bed reactor with nanostructure titania coated Raschig rings," Chemical Engineering Journal, vol. 151, no. 1-3, pp. 295-301, 2009. 

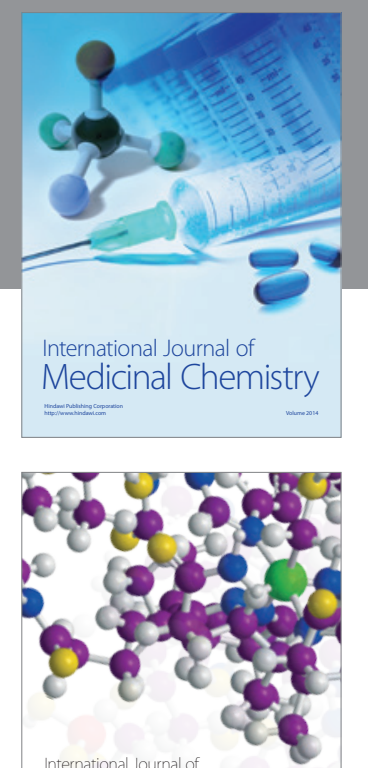

\section{Carbohydrate} Chemistry

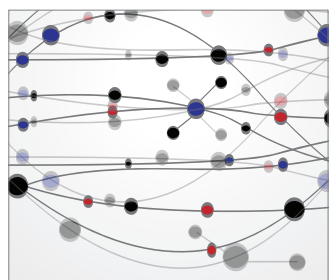

The Scientific World Journal
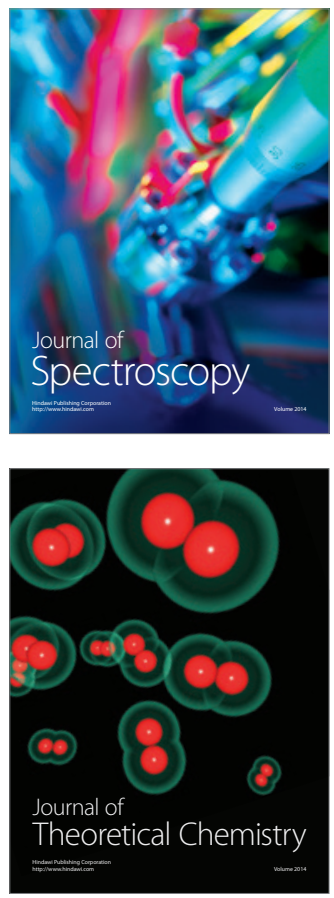
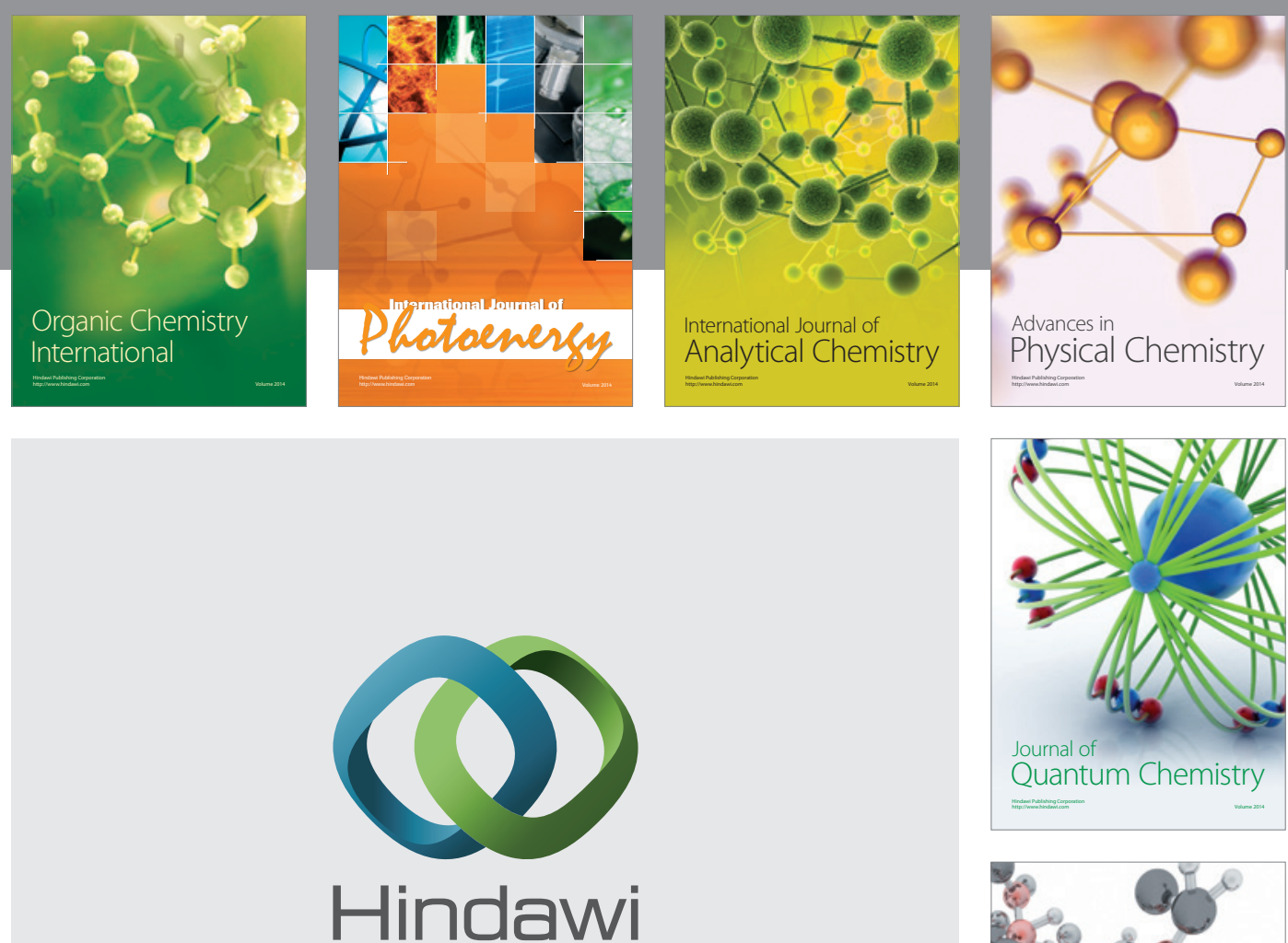

Submit your manuscripts at

http://www.hindawi.com

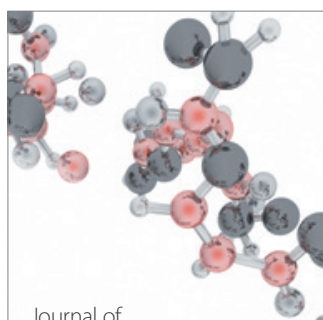

Analytical Methods

in Chemistry

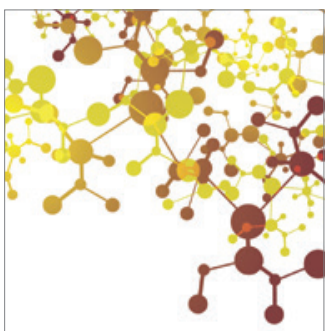

Journal of

Applied Chemistry

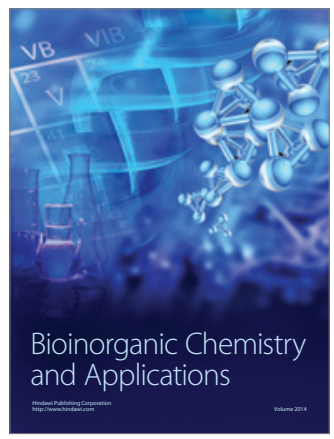

Inorganic Chemistry
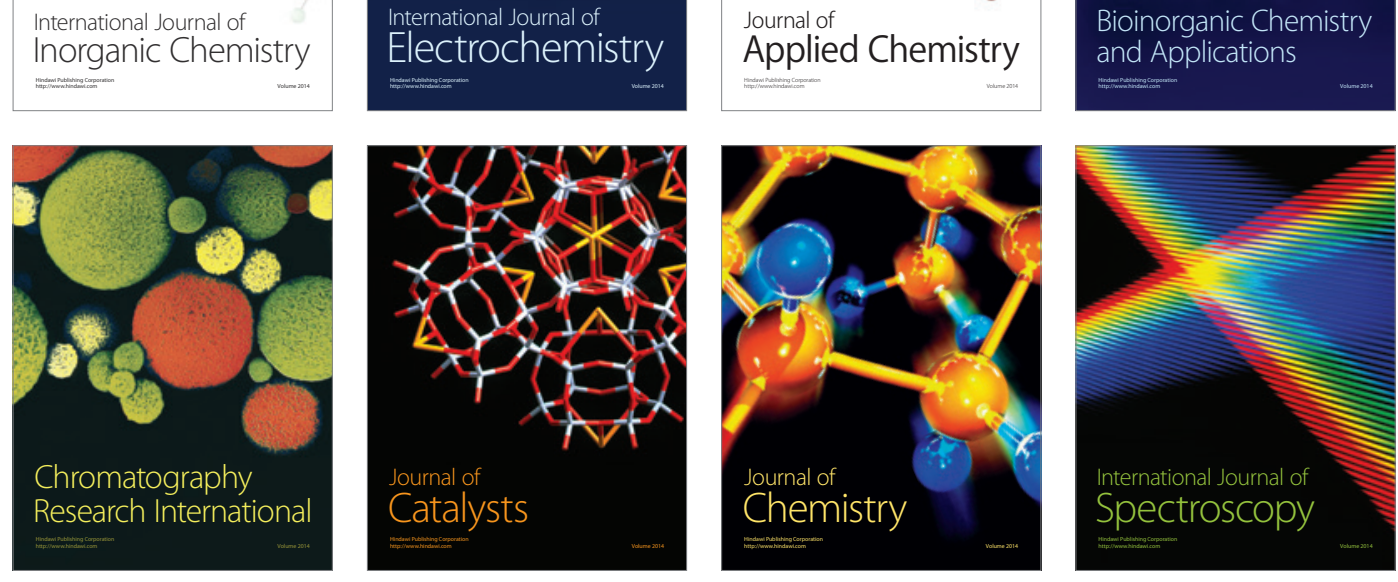